\title{
Supplementation with protected fat to manage gastro-intestinal nematode infections in Santa Ines sheep
}

\section{Suplementação com gordura protegida na infecção por nematódeos gastrintestinais em ovelhas Santa Inês}

\author{
Vivian Alves Costa Afonso ${ }^{1}$; Ricardo Lopes Dias Costa ${ }^{2 *}$ \\ Cecílio Viega Soares Filho; ; Eduardo Antonio da Cunha²; \\ Silvia Helena Venturoli Perri ${ }^{3}$; Fábio Luiz Bonello ${ }^{4}$
}

\begin{abstract}
This experiment aimed to determine the influence of supplementation with protected fat on nematode infections in periparturient sheep or sheep in their final stage of pregnancy. Fifty Santa Ines ewes received $200 \mathrm{~g}$ of concentrate/animal/day, mineral salt and water and were grouped according to their weight, hematocrit and the number of eggs per gram of feces (EPG). Two diets were used: a control treatment and a treatment consisting of supplementation with $30 \mathrm{~g} / \mathrm{animal} / \mathrm{day}$ of protected fat in the concentrate. Three monthly evaluations were performed over a total of 84 days of testing. The variables analyzed were weight, body condition, EPG and coprocultures; blood tests were performed for the determination of packed cell volume, hemoglobin concentration and total plasma protein, and leukograms and eosinophil counts were performed. For weight and hemoglobin concentrations, interactions were observed between diet and collection date $(\mathrm{P}<0.05)$; body condition, total plasma protein, packed cell volume and total leukocytes did not differ statistically among treatments $(\mathrm{P}>0.05)$ but did differ by collection day $(\mathrm{P}<0.05)$. The EPG and eosinophil counts did not differ statistically by either diet or collection date $(\mathrm{P}>0.05)$. The genus Haemonchus was predominant, followed by the genera Cooperia, Trichostrongylus and Oesophagostomum. The protected fat did not decrease EPG and did not improve the blood parameters of infected sheep.
\end{abstract}

Key words: Polyunsaturated fatty acids, nutrition, sheep, Haemonchus

\section{Resumo}

O objetivo do experimento foi verificar a influência da suplementação com gordura protegida na infecção por nematódeos gastrintestinais em ovelhas Santa Ines no periparto ou terço final de gestação. Cinquenta ovelhas Santa Inês receberam $200 \mathrm{~g}$ de concentrado/animal/dia, sal mineral e água, sendo divididas de acordo com peso, número de ovos por grama de fezes (OPG) e porcentagem do hematócrito em duas dietas, consideradas como tratamento controle e tratamento com suplementação de $30 \mathrm{~g} / \mathrm{dia} / \mathrm{animal}$ de gordura protegida no concentrado. Duas avaliações mensais foram realizadas durante três meses, totalizando 84 dias de experimentação. As variáveis analisadas foram peso e condição corporal, OPG e coprocultura, contagem de leucócitos e eosinófilos, verificação do volume globular, concentração de

${ }^{1}$ Prof $f^{\text {a }}$ do Centro Paula Souza, Rio das Pedras, SP. E-mail: vivianveterinaria@hotmail.com

${ }^{2}$ Pesquisadores Científico(s), Instituto de Zootecnia, IZ/APTA/SAA, R. Heitor Penteado, 56, CEP 13460-000, Nova Odessa, SP. E-mail: rldcosta@iz.sp.gov.br; cunha@iz.sp.gov.br

${ }^{3}$ Profs. Assistente Drs. do Dept ${ }^{\circ}$ de Apoio, Produção e Saúde Animal, Curso de Medicina Veterinária, UNESP/FOA, Araçatuba, 16050-680, Araçatuba, SP. E-mail: cecilio@fmva.unesp.br; shperri@fmva.unesp.br

${ }^{4}$ Médico Veterinário, M.e. em Ciência Animal, R. Capitão Bernardes, 857, CEP: 13480-790, Limeira, SP. E-mail: bonellofl@ yahoo.com.br

* Author for correspondence 
hemoglobina e dosagem de proteína plasmática total. Em relação as variáveis peso e hemoglobina, houve interação entre as dietas e as coletas $(\mathrm{P}<0,05)$; as variáveis condição corporal, proteína plasmática total, volume globular e leucócitos totais não apresentaram diferença estatística entre as dietas $(\mathrm{P}>0,05)$ mas sim durante as coletas $(\mathrm{P}<0,05)$. As variáveis $\mathrm{OPG}$ e eosinófilos não apresentaram diferença estatística $(\mathrm{P}>0,05)$. O gênero Haemonchus foi predominante, seguido pelos gêneros Cooperia, Trichostrongylus and Oesophagostomum A suplementação com gordura protegida na quantidade de $30 \mathrm{~g} / \mathrm{animal} / \mathrm{dia}$, não interferiu na diminuição do OPG ou melhora dos parâmetros sanguíneos em infecção parasitária nas ovelhas deste estudo.

Palavras-chave: Ácidos graxos poliinsaturados, nutrição, ovinos, Haemonchus

\section{Introduction}

Resistance to anthelmintic drugs represents an obstacle to sheep breeding. Alternative measures for the control of helminths include improved nutrition (BRICARELLO et al., 2005; HOUDIJK et al., 2005), homeopathy (CAVALCANTI; ALMEIDA; DIAS, 2007; ZACHARIAS et al., 2007), phytotherapy (CHANDRAWATHANI et al., 2006; CHAGAS et al., 2008), treatment with plant tannins (CENCI et al., 2007; MINHO et al., 2008, 2010), supplementation with minerals (GONCALVES; ECHEVARRIA, 2004) and the use of nematophagous fungi (GRAMINHA et al., 2001, 2005; ROCHA; ARAÚJO; AMARANTE, 2007).

Haemonchus contortus is a major threat to sheep breeding, and pathogenicity and resistance to many anthelmintic drugs has developed in many places (AMARANTE et al., 1997). However, other gastrointestinal parasites of lower pathogenicity, such as Trichostrongyloidea (Trichostrongylus, Cooperia and Oesophagostomum), Strongyloides spp., Eimeria spp. and Moniezia spp., are also problematic and should be considered.

Many studies on the interaction between protein and infections with ovine nematodes have been conducted (STEEL, 2003; LOUVANDINI et al., 2006); however, studies of the influence of dietary energy on the control of worms, particularly in tropical conditions, are necessary (HOSTE et al., 2005).

Supplementation with oil or protected fat sources containing fatty acids of the n-3 and n- 6 families (which are essential to ruminants) represents an interesting strategy for helminth control, as these fats can influence the regulation of the immune expression and the inflammatory response of eicosanoid-mediated immune-effectors (HWANG, 2000). Muturi et al. (2005) describe the actions of polyunsaturated fatty acids on the nematode burden of ruminants.

The goal of this experiment was to determine the influence of supplementation with protected fat on gastrointestinal nematode infections in periparturient sheep or sheep in their final stage of pregnancy.

\section{Materials and Methods}

\section{Experimental site, animals and feed management}

The experiment was conducted in Andradina, São Paulo State, Brazil. In August, September and October of 2007, the average rainfall was 0, 0 and $56 \mathrm{~mm}$, respectively. The average maximum and minimum temperatures were $35.3^{\circ} \mathrm{C}$ and $14.4^{\circ} \mathrm{C}$, respectively, and the average temperature was $25.1^{\circ} \mathrm{C}$ during the trial (Source: Meteorological Station of APTA - Agência Paulista de Tecnologia dos Agronegócios).

A total of 50 Santa Ines ewes between one and three years old were placed on 2.5 hectares of pasture; the pasture was divided into four paddocks, two with Panicum maximum cv. Aruana grass (28\% dry matter, $7.17 \%$ crude protein, $52 \% \mathrm{ADF}, 80.17 \%$ NDF, 39.88\% Cellulose and $8.18 \%$ Lignin) and two with Áries grass (29\% dry matter, $7.26 \%$ of crude protein, 53.56\% ADF, 80.22\% NDF, 40.29\% Cellulose and $9.76 \%$ Lignin). 
The animals were rotated between the four paddocks and provided with free access to water and mineral salt for fourteen days before the start of the experiment.

\section{Experimental design}

According to their packed cell volume, number of eggs per gram of feces and live weight, sheep were assigned to either a control or a treatment diet consisting of supplementation with $30 \mathrm{~g} / \mathrm{animal} /$ day of protected fat (Megalac $\mathrm{E}^{\mathrm{R}^{*}}$ ); diets were otherwise isonitrogenous and isocaloric. The animals were fed twice a day (100 $\mathrm{g}$ at 08:00 and $100 \mathrm{~g}$ at 16:00) with a concentrate mixture containing corn grain, soybean meal, mineral mix and lime $(18 \%$ crude protein and $6 \%$ ether extract).

Seventy-eight percent of the ewes lambed during the experiment; $48 \%, 8 \%$ and $16 \%$ of the control group (20 lambs) and $64 \%, 12 \%$ and $8 \%$ of the treatment group (25 lambs), lambed in August, September and October, respectively.

Twice a month, the sheep were individually weighed and assigned a body condition score; stool and blood samples for coprological and hematological laboratory tests, respectively, were collected twice a month over the 84 days of testing.

\section{Measurements}

Weights were measured with a mechanical balance. Body condition (CC) was determined by palpation of the lumbar region to assess the coverage of fat; a score of 1 to 5 was assigned, where 1 represents cachectic, 2 thin, 3 satisfactory, 4 fat and 5 obese (SAÑUDO; SIERRA, 1986). Half points could be assigned, as recommended by Pugh (2004). The fecal samples were processed with
Gordon and Whitlock's modified technique (1939); coprocultures were also performed (ROBERTS; O'SULLIVAN, 1950). Analyses of the packed cell volume (PCV), hemoglobin concentration $(\mathrm{Hb})$, and total plasma protein (TPP) were performed; total leukocytes and eosinophils were also counted (SCHALM; CARROL, 1986).

\section{Treatment with anthelmintics}

Treatments were administered when the sheep had a PCV less than or equal to $20 \%$. Levamisole phosphate $\left(0.1 \mathrm{ml} / \mathrm{kg}\right.$ of Ripercol ${ }^{\circledR} \mathrm{L} 150 \mathrm{~F}$, Fort Dodge) was administered subcutaneously. The choice of anthelmintic was based on the fact that a fecal egg count reduction test performed prior to the experiment (2006) found that this drug had 85\% effectiveness. The fecal egg count reduction test is a practical and inexpensive test appropriate for all anthelmintic drugs and only requires the technician to be able to perform egg per gram counts (COLES, 2005).

\section{Statistical analysis}

The variables analyzed were individual weight, body condition, packed cell volume, total plasma protein, hemoglobin, total leukocytes, eosinophils and number of eggs per gram of feces (EPG). We assessed the normality of the data using the Proc Univariate command of the SAS program (version 8.2); EPG data and number of eosinophils were $\log _{10}$ $(\mathrm{x}+1)$ transformed. The data from the two diets were compared using analysis of variance (PROC GLM). The Student-Newman-Keuls (SNK) test at $5 \%$ probability (SAS, 1999) was used to compare the means.

\footnotetext{
* Calcium salts of soybean oil - linoleic acid 40-42\%, linolenic acid 2,7-3\%, oleic acid 32.3\%, palmitic acid $16.3 \%$ and stearic acid $4.8 \%$.
} 


\section{Results}

\section{Treatment with anthelmintics}

Twenty-three and 21 treatments were administered in the control diet and treatment diet, respectively. In the control diet (15 sheep), one sheep needed four treatments, one was treated three times, three sheep were treated twice, ten sheep were treated once and ten sheep did not need anthelmintics (40\%); in the protected fat diet (14 sheep), two sheep were treated three times, three sheep were treated twice, nine sheep were treated once, and 11 did not need treatment (44\%).

\section{Parasitological analysis}

At the beginning of the experiment (collection 1), feces from all sheep were examined for eggs (control diet $1808 \pm 2372 \times 1813 \pm 1694$ protected fat diet, $\mathrm{P}>0.05)$. The mean number of eggs did not differ statistically by treatment $(\mathrm{P}>0.05)$. The mean EPG counts of animals in the control diet and in the treatment diet and the number of sheep treated with anthelmintics according to their packed cell volume are shown in Figure 1.

In this work, the nematode burdens were high. The average numbers of eggs per gram were $2546 \pm 3501$ and $2549 \pm 2436$ in the control diet and treatment diet, respectively; maximum values were $3355 \pm 3571$ (control diet collection 2) and $4026 \pm 3242$ (protected fat diet collection 4), respectively. Figure 2 shows the frequency distribution of eggs per gram of feces of sheep by diet.

The genus Haemonchus was the most abundant larva identified, with an average prevalence of $62 \%$ in animals of the control diet and $57 \%$ in animals of the protected fat diet (Figure 3); the genera Cooperia, Trichostrongylus and Oesophagostomum were second in abundance to Haemonchus. Trichostrongylus and Cooperia were most abundant in fecal samples from collections 2 and 6 , respectively, in animals on the treatment diet.

Figure 1. Mean and standard deviation of eggs per gram of faeces (EPG) and the number of sheep treated individually with anti-helminthes, according to the control diet (C) or protected fat (PF) in each collection.

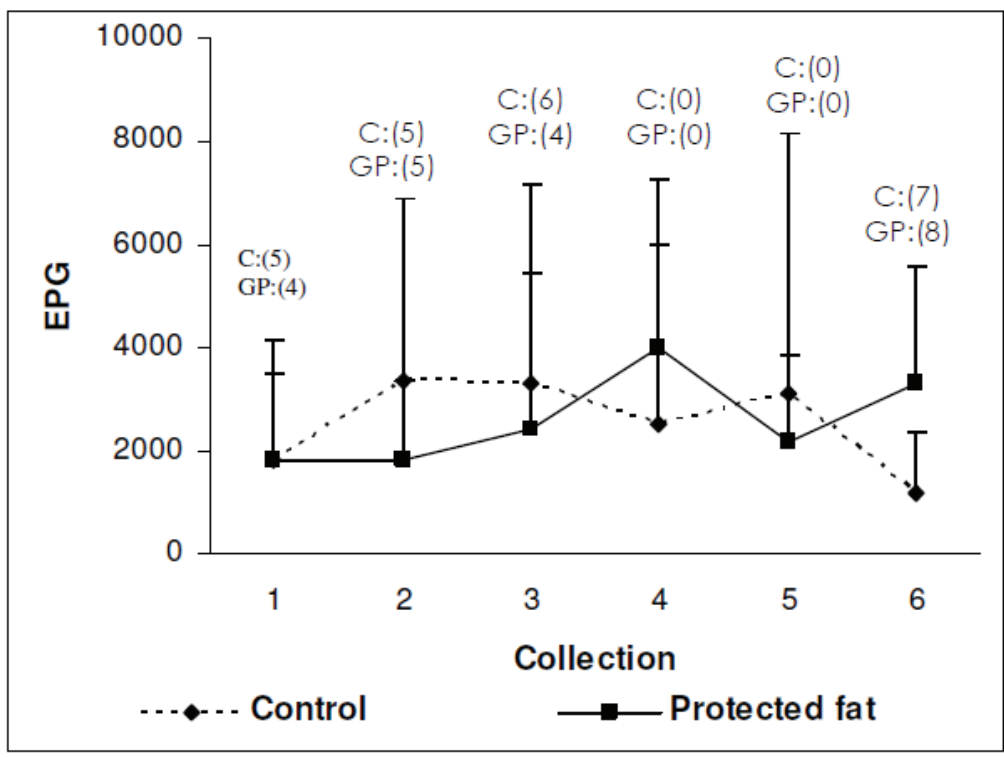

Source: Elaboration of the authors. 
Figure 2. Frequency distribution of eggs per gram of feces (EPG) of sheep, according to the control or protected fat diets.

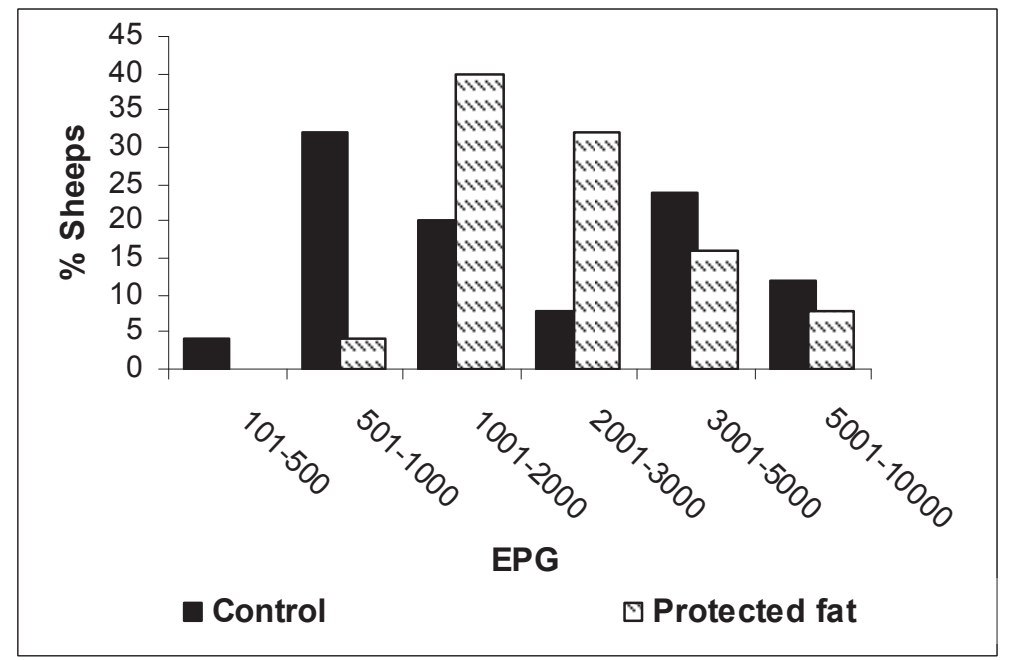

Source: Elaboration of the authors.

Figure 3. Frequency distribution of the genus Haemonchus spp, according to the control or protected fat diets.

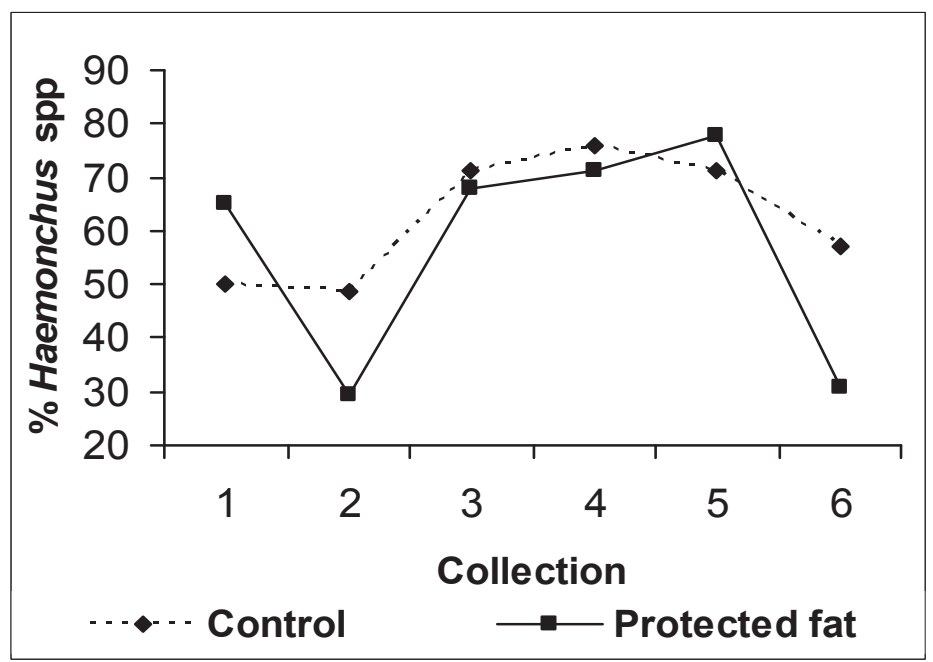

Source: Elaboration of the authors.

The prevalence of Haemonchus spp, in the treatment diet was $19 \%, 3 \%, 5 \%$ and $26 \%$ lower than in the control diet at collections 2, 3, 4 and 6, respectively.

\section{Hematological analysis}

The hematological parameters are shown in Table 1 according to diet and collection date. There were no significant differences in hematological variables between the two diets $(\mathrm{P}>0.05)$. The mean 
values of total plasma protein, packed cell volume and total leukocytes were significantly different between collection dates $(\mathrm{P}<0.05)$, while the mean number of eosinophils did not differ. The highest mean values $(\mathrm{P}<0.05)$ of total plasma protein and packed cell volume, which were statistically similar, were found in samples 4 and 5, respectively.
As shown in Figure 4, there was an interaction between collection date and diet for hemoglobin, which ranged from $79.44 \pm 13.73 \mathrm{~g} / \mathrm{L}$ (control diet / collection 2) to $98.98 \pm 16.79 \mathrm{~g} / \mathrm{L}$ (protected fat diet/ collection 6).

Table 1. Means and standard desviation of hematological variables of Santa Ines sheep of control and protected fat diet.

\begin{tabular}{ccccc}
\hline Diets & TPP $(\mathrm{g} / \mathrm{L})$ & PCV $(\%)$ & Leuc $\left(x 10^{9} / \mathrm{L}\right)$ & Eosin $\left(x 10^{9} / \mathrm{L}\right)$ \\
\hline Control & $62.50 \pm 4.80^{\mathrm{a}}$ & $25.39 \pm 4.42^{\mathrm{a}}$ & $8.37 \pm 2.47^{\mathrm{a}}$ & $0.51 \pm 0.47^{\mathrm{a}}$ \\
Protected fat & $62.46 \pm 4.41^{\mathrm{a}}$ & $25.06 \pm 4.27^{\mathrm{a}}$ & $7.79 \pm 1.81^{\mathrm{a}}$ & $0.57 \pm 0.75^{\mathrm{a}}$ \\
\hline Collections & & & & \\
1 & $60.5 \pm 3.45^{\mathrm{b}}$ & $24.4 \pm 3.28^{\mathrm{b}}$ & $9.4 \pm 2.24^{\mathrm{a}}$ & $0.5 \pm 0.48^{\mathrm{a}}$ \\
2 & $59.8 \pm 5.07^{\mathrm{c}}$ & $23.6 \pm 3.77^{\mathrm{bc}}$ & $7.8 \pm 1.81^{\mathrm{b}}$ & $0.4 \pm 0.45^{\mathrm{a}}$ \\
3 & $62.0 \pm 3.85^{\mathrm{c}}$ & $23.4 \pm 3.81^{\mathrm{bc}}$ & $7.6 \pm 1.91^{\mathrm{b}}$ & $0.5 \pm 0.95^{\mathrm{a}}$ \\
4 & $66.0 \pm 3.72^{\mathrm{a}}$ & $28.6 \pm 3.48^{\mathrm{a}}$ & $7.6 \pm 2.53^{\mathrm{b}}$ & $0.6 \pm 0.67^{\mathrm{a}}$ \\
5 & $64.6 \pm 3.85^{\mathrm{a}}$ & $28.7 \pm 3.40^{\mathrm{a}}$ & $7.3 \pm 1.52^{\mathrm{b}}$ & $0.5 \pm 0.51^{\mathrm{a}}$ \\
6 & $61.9 \pm 4.28^{\mathrm{b}}$ & $22.6 \pm 3.83^{\mathrm{c}}$ & $8.9 \pm 2.16^{\mathrm{a}}$ & $0.7 \pm 0.59^{\mathrm{a}}$ \\
\hline
\end{tabular}

Means in the same row with different letters are statistically different by SNK test $(\mathrm{P}<0.05)$. TPP $=$ total plasma protein; $\mathrm{PCV}=$ packet cell volume; Leuc $=$ total leukocytes; Eosin $=$ eosinophils.

Source: Elaboration of the authors.

Figure 4. Mean and standard deviation of hemoglobin variable (g / L) of Santa Ines sheep, according to the control or protected fat diet.

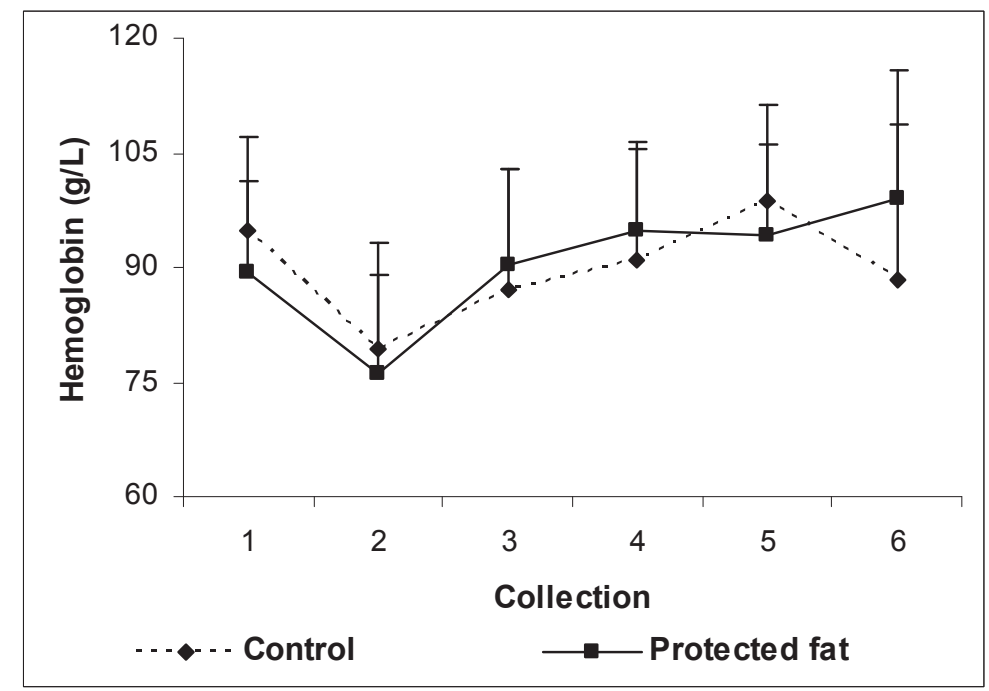

Source: Elaboration of the authors. 


\section{Weight and body condition}

An interaction between diet and collection was observed for weight. The weights increased from collection 1 to collection 4 in the control diet, then decreased at collection 6 while remaining statistically similar to weights from previous collections and different from others $(\mathrm{P}<0.05)$. In the protected fat diet, the mean weights of the 6 collection periods were less than those of all other samples $(\mathrm{P}<0.05)$. The weights of the animals on the control diet at collections 4, 5 and 6 were higher than those of the animals on the protected fat diet $(\mathrm{P}$ $<0.05$ ) (Table 2).

The mean values of body condition scores showed no statistically significant differences ( $\mathrm{P}>$ 0.05) among diets (Table 3).

Table 2. Means and standard deviation of variable weight $(\mathrm{kg})$ of sheep Santa Ines, according to the diets and collections.

\begin{tabular}{ccc}
\hline & \multicolumn{2}{c}{ Diets } \\
\cline { 2 - 3 } Collections & Control & Protected fat \\
\cline { 2 - 3 } 1 & $40.6 \pm 4.90^{\mathrm{aA}}$ & $41.9 \pm 4.09^{\mathrm{abA}}$ \\
2 & $42.6 \pm 5.87^{\mathrm{bA}}$ & $41.0 \pm 4.50^{\mathrm{abA}}$ \\
3 & $43.1 \pm 5.43^{\mathrm{bA}}$ & $42.6 \pm 5.23^{\mathrm{aA}}$ \\
4 & $44.2 \pm 5.80^{\mathrm{bA}}$ & $42.4 \pm 5.45^{\mathrm{aB}}$ \\
5 & $43.4 \pm 6.30^{\mathrm{bA}}$ & $40.6 \pm 4.27^{\mathrm{bB}}$ \\
6 & $41.0 \pm 6.06^{\mathrm{aA}}$ & $38.3 \pm 4.62^{\mathrm{cB}}$ \\
\hline
\end{tabular}

Means followed by different superscript letters lowercase in row and capitals in line are statistically different by SNK test (P $<0.05)$. Source: Elaboration of the authors.

Table 3. Means and standard deviation of body condition variable of ewes Santa Ines of control diet and protected fat.

\begin{tabular}{cc}
\hline Diets & Body condition \\
\hline Control & $2.7 \pm 0.43^{\mathrm{a}}$ \\
Protected fat & $2.6 \pm 0.57^{\mathrm{a}}$ \\
\hline Collections & $2.6 \pm 0.41^{\mathrm{ab}}$ \\
1 & $2.6 \pm 0.46^{\mathrm{ab}}$ \\
2 & $2.7 \pm 0.58^{\mathrm{a}}$ \\
3 & $2.7 \pm 0.62^{\mathrm{a}}$ \\
4 & $2.6 \pm 0.54^{\mathrm{ab}}$ \\
5 & $2.5 \pm 0.48^{\mathrm{b}}$ \\
\hline
\end{tabular}

Means followed by different superscript letters lowercase in row are statistically different by SNK test $(\mathrm{P}<0.05)$.

Source: Elaboration of the authors.

\section{Discussion}

The animals of the experiment had high mean values of EPG despite the fact that the Santa Ines breed is considered more resistant to nematodes than other breeds (BRICARELLO et al., 2005; COSTA et al. 2007). Rocha, Amarante e Bricarello (2004) reported that Santa Ines sheep in the first months of lactation had a maximum of 647 eggs per gram of feces, which was far below the values encountered in this work (2547 EPG).

The periparturient status of sheep has been found to contribute to increased numbers of nematode eggs 
(AMARANTE et al., 2004; ROCHA; AMARANTE; RICARELLO, 2004). Although 78\% of the sheep lambed during the experiment, the high EPG did not appear to be related to the periparturient status of the sheep, and no significant differences in the number of eggs were found between the diets.

Donaldson et al. (1998) reported a greater immunity against parasitic infections in sheep supplemented with fish oil. The fish oil, unlike the supplements used in this experiment, is a source of linoleic acid; when offered directly in the diet, this fat is subject to biohydrogenation which could diminish its beneficial effects.

Amarante (2002) reported that the immune response of sheep is not the same in a herd where most of the sheep harbor a small proportion of the worms. In this work, as shown in Figure 2, a low percentage of ewes had either few (4\% and $0 \%$ of the sheep on the control and protected fat diet, respectively, had $<500)$ or many eggs $(12 \%$ and $8 \%$ of the sheep on the control and protected fat diet, respectively, had $>5000$ ).

Despite the high EPGs encountered in sheep of this experiment, $42 \%$ of the sheep did not need anthelmintics throughout the experiment, while ten sheep $(20 \%)$ received more than one application. The expression of immunity against gastrointestinal nematodes, which makes the animals resistant or resilient, can vary widely among animals of the same flock (STEAR; MURRAY, 1994); this observation confirms the unexpected finding that certain animals required more deworming than others, as all animals were raised in the same environment with the same management conditions.

Several authors have described the prevalence of Haemonchus contortus in sheep (ROCHA; PACHECO; AMARANTE, 2007). Amarante et al. (1999) observed increases in the percentage of Cooperia spp. and Trichostrongylus spp in cultures of samples with low counts of EPG.

The decrease in the occurrence of Haemonchus (KAPLAN et al., 2004) suggests a smaller proportion of this type of parasite, which could lead to a lower rate of oviposition and a consequent reduction in the contamination of pastures (MORTENSEN et al., 2003).

Infection with $H$. contortus can cause severe anemia and hypoproteinemia (FARIA JUNIOR et al., 2002), depression, loss of body condition, reduced productivity and eventual death (KAPLAN et al., 2004). In this experiment, no animal died; this was most likely due to periodic evaluations and interventions with anthelmintics when necessary. The protected fat was not effective in reducing the number of animals that needed to be dewormed or in improving the mean values of PCV, TPP, $\mathrm{Hb}$, total leukocytes, eosinophils and body condition score.

Results showed that, in the early stages of infection, the evaluation of hematocrit parameters was not sensitive enough to show changes induced by hemonchosis; in general, the hemoglobin concentration is the best parameter with which to evaluate the degree of anemia (ZACHARIAS et al., 2007).

In sheep, gastrointestinal parasitic infections are generally accompanied by eosinophilia (HUNTLEY et al., 1998). In this experiment, no eosinophilia was observed, most likely because the animals were already infected before the experiment (collection 1> 1800 OPG); a similar observation was made by Amarante (2002).

Body weight is an indirect and fairly insensitive measure for assessing the nutritional status of sheep. More practical and accurate direct assessments of the nutritional status of a flock have been performed in several works (GUNN et al., 1991). The fact that many of the sheep lambed during the experiment is also noteworthy, as the variation in mean weight among the animals could be due to their physiological status. The lowest mean value was found at the last collection in animals on the protected fat diet; this is likely related to the fact that $84 \%$ of the sheep in this group lambed, while only $72 \%$ of the animals on the control diet lambed during the experiment. Because 
the diets were isocaloric and isonitrogenous, the mean body condition score of animals was the same in both diets. Several studies reported an inverse relationship between supplementation with protected fat and voluntary consumption of cow milk, even leading to a decrease in body condition (EZEQUIEL, 2001).

According to Coop and Kyriazakis $(1999,2001)$ and Costa et al. (2007), protein supplementation decreases parasitism in sheep. The diets used in this study provided only $82 \%$ and $91 \%$ of the daily requirements for protein and energy (TDN), respectively, to prevent a possible effect of the supplemental protected fat.

Timing the immune response to the stage of infection and enriching the intestine with polyunsaturated fatty acids in the beginning of life may promote a good immune response against gastrointestinal parasites (MUTURI et al., 2005); providing the protected fat in the creep-feeding of lambs in the pre-weaning stage may yield better results.

In conclusion, the supplementation with protected fat yielded no decrease in EPG and no improvement in blood parameters in infected Santa Ines sheep.

\section{Acknowledgments}

To Recanto Sereno Ranch by the animals loan.

\section{References}

AMARANTE, A. F. T. Resistência de cordeiros das raças Santa Ines, Suffolk e Ile de France as infecções naturais por nematódeos gastrintestinais. 2002. Tese (Livre Docência) - Universidade Estadual Paulista, Botucatu.

AMARANTE, A. F. T.; BAGNOLA JUNIOR, J.; AMARANTE, M. R. V.; BARBOSA, M. A. Host specificity of sheep and cattle nematodes in São Paulo state. Brazil. Veterinary Parasitology, Amsterdam, v. 73, n. 1-2, p. 89-104, 1997.
AMARANTE, A. F. T.; CRAIG, T. M.; EL-SAYDE, N. M.; DESOUKI, A. Y.; RAMSEY, W. S.; BAZER, F. W. Comparison of naturally acquired parasite burdens among Florida Native, Rambouillet and crossbreed ewes. Veterinary Parasitology, Amsterdam, v. 85, n. 1, p. 6169, 1999.

AMARANTE, A. F. T.; BRICARELLO, P. A.; ROCHA, R. A.; GENNARI, S. M. Resistance of Santa Ines, Suffolk and Ile de France sheep to naturally acquired gastrointestinal nematode infections. Veterinary Parasitology, Amsterdam, v. 120, n. 1-2, p. 91-106, 2004.

BRICARELLO, P. A.; AMARANTE, A. F. T.; ROCHA, R. A.; CABRAL FILHO, S. L.; HUNTLEY, J. F.; HOUDIJK, J. G. M.; ABDALLA, A. L.; GENNARI, S. $M$. Influence of dietary protein supply on resistance to experimental infections with Haemonchus contortus in Ile de France and Santa Ines lambs. Veterinary Parasitology, Amsterdam, v. 134, n. 1-2, p. 99-109, 2005.

CAVALCANTI, A. S. R.; ALMEIDA, M. A. O.; DIAS, A. V. S. Efeito de medicamentos homeopáticos no número de ovos de nematódeos nas fezes (OPG) e no ganho de peso em ovinos. Revista Brasileira de Saúde e Produção Animal, Salvador, v. 8, n. 3, p. 162-169, 2007.

CENCI, F. B.; LOUVANDINNI, H.; MCMANUS, C. M.; DELL'PORTO, A.; COSTA, D. M.; ARAÚJO, S. C.; MINHO, A. P.; ABDALLA, A. L. Effects of condensed tannin from Acacia mearnsii on sheep infected naturally with gastrointestinal helmintes. Veterinary Parasitology, Amsterdam, v. 144, n. 1-2, p. 132-137, 2007.

CHAGAS, A. C. S.; VIEIRA, L. S.; FREITAS, A. R.; ARAÚJO, M. R. A.; ARAÚJO-FILHO, J. A.; ARAGUÃO, W. R.; NAVARRO, A. M. C. Anthelmintic efficacy of neem (Azadirachta indica a. juss) and the homeopathic product Fator Vermes ${ }^{\circledR}$ in Morada Nova sheep. Veterinary Parasitology, Amsterdam, v. 151, n. 1, p. 68-73, 2008.

CHANDRAWATHANI, P.; CHANG, K. W.; NURULAINE, R.; WALLER, P. J.; ADNAN, M.; ZAINI, C. M.; JAMNAH, O.; KHADIJAH, S.; VINCENT, N. Daily feeding of fresh Neem leaves (Azadirachta indica) for worm control in sheep. Tropical Biomedicine, Malasia, v. 23, n. 1, p. 23-30, 2006.

COLES, G. C. Anthelmintic resistnace - looking to the future: a UK perspective. Research Veterinary Science, Rome, Italy, v. 78, n. 2, p. 99-108, 2005.

COOP, R. L.; KYRIAZAKIS, I. Influence of host nutrition on the development and consequences of nematode parasitism in ruminants. Trends Parasitology, Cambridge, v. 17, n. 1, p. 325-330, 2001. 
Nutrition-parasite interaction. Veterinary Parasitology, Amsterdam, v. 84, n. 3-4, p. 187-204, 1999.

COSTA, R. L. D.; BUENO, M. S.; VERISSIMO, C. J.; CUNHA, E. A.; SANTOS, L. E.; OLIVEIRA, S. M.; SPOSITO FILHA, E.; OTSUK, I. P. Performance and nematode infection of ewe lambs on intensive rotational grazing with two different cultivars of Panicum maximum. Tropical Animal Health Production, Netherlands, v. 39, n. 4, p. 255-263, 2007.

DONALDSON, J.; VAN HOUTERT, M. F. J.; SYKES, A. R. The effect of nutrition on the periparturient parasite status of mature ewes. Journal of Animal Science, Champaign, v. 67, n. 3, p. 523-533, 1998.

EZEQUIEL, J. M. B. Uso de caroço de algodão na alimentação animal. In: SIMPÓSIO GOIANO SOBRE MANEJO E NUTRIÇÃO DE BOVINOS, 3., 2001. Goiânia. Anais... Goiânia: CBNA, 2001. p. 307-328.

FARIA JUNIOR, S. P.; SILVA, M. M.; SCHEIBEL, M.; MARTINS, M. F.; RABELLO, P.; BERTAGNON, H. G.; GARCIA, M. Uso da contagem fecal de ovos de nematoides (OPG) para estimar a condição clínica em caprinos. Ciências Veterinárias nos Trópicos, Recife, v. 5, p. 86-92, 2002.

GONÇALVES, G. I.; ECHEVARRIA, F. A. M. Cobre no controle da verminose gastrintestinal em ovinos. Ciência Rural, Santa Maria, v. 34, n. 1, p. 183-188, 2004.

GORDON, H. M. C. L.; WHITLOCK, H. V. A new technique for counting nematode eggs in sheep faeces. Journal of the Council for Scientific and Industrial Research, v. 12, p. 50-52, 1939.

GRAMINHA, E. B. N.; COSTA, A. J.; OLIVEIRA, G. P.; MONTEIRO, A. C.; PALMEIRA, S. B. S. Biological control of sheep parasite nematodes by nematodetrapping fungi: in vitro activity and after passage through the gastrointestinal tract. World Journal of Microbiology \& Biothecnology, Netherlands, v. 21, n. 5, p. 710-722, 2005.

GRAMINHA, E. B. N.; MAIA, A. S.; SANTOS, J. M.; CANDIDO, R. C.; SILVA, G. S.; COSTA, A. J. Avaliação in vitro da patogenicidade de fungos predadores de nematóides parasitos de animais domésticos. Semina: Ciencias Agrarias, Londrina, v. 22, n. 1, p. 1-16, 2001.

GUNN, R. G.; MAXWELL, T. J.; SIM, D. A.; JONES, J. R.; JAMES, M. E. The effect of level of nutrition prior to mating on the reproductive performance of ewes of two Welsh breeds in different levels of body condition. Animal Production, Cambridge, v. 52, n. 1, p. 157-163, 1991.
HOSTE, H.; TORRES-ACOSTA, J. F.; PAOLINI, V.; AGUILAR-CABALLERO, A.; ETTER, E.; LEFRILEUX, Y.; CHARTIER, C.; BROQUA, C. Interactions between nutrition and gastrointestinal infections with parasitic nematodes in goats. Small Ruminant Research, Amsterdan, v. 60, n. 1-2, p. 141-151, 2005.

HOUDIJK, J. G. M.; KYRIAZAKIS, I.; JACKSON, F.; HUNTLEY, J. F.; COOP, R. L. Effects of protein supply and reproductive status on local and systemic immune responses to Teladorsagia circumcincta in sheep. Veterinary Parasitology, Amsterdam, v. 129, n. 1-2, p. 105-117, 2005.

HUNTLEY, J. F.; SCHALLIG, H. D. F. H.; KOOYMAN, F. N. J.; MACKELLAR, A.; JACKSON, F.; SMITH, W. D. IgE antibody during infection with the ovine abomasal nematode, Teladorsagia circumcincta, primary and secondary responses in serum and gastric lymph of sheep. Parasite Immunology, Oxford, v. 20, n. 11, p. 565571, 1998.

HWANG, D. Fatty acids and immune responses - a newperspective in searching for clues to mechanism. Annual Review of Nutrition, Califórnia, v. 20, n. 1, p. 431-456, 2000.

KAPLAN, R. M.; BURKE, J. M.; TERRILL, T. H.; MILLER, J. E.; GETZ, W. R.; MOBINI, S.; VALENCIA, E.; WILLIAMS, M. J.; WILLIAMSOM, L. H.; LARSEN, M.; VATTA, A. F. Validation of the FAMACHA eye color chart for detecting clinical anemia in sheep and goats on farms in the southern United States. Veterinary Parasitology, Amsterdam, v. 123, n. 1-2, p. 105-120, 2004.

LOUVANDINI, H.; VELOSO, C. F. M.; PALUDO, G. R.; DELL'PORTO, A.; GENNARI, S. M.; MCMANUS, C. M. Influence of protein supplementation on the resistence and resilience on young hair sheep naturally infected with gastrointestinal nematodes during rainy and dry seasons. Veterinary Parasitology, Amsterdam, v. 137, n. 1-2, p. 103-111, 2006.

MINHO, A. P.; BUENO, I. C. S.; LOUVANDINNI, H.; JACKSON, F.; GENNARI, S. M.; ABDALLA, A. L. Effect of Acacia molissima tannin extract on the control of gastrointestinal parasites in sheep. Animal Feed Science and Technology, Amsterdam, v. 147, n. 1-3, p. 172-181, 2008.

MINHO, A. P.; GENNARI, S. M.; AMARANTE, A. F. T.; ABDALLA, A. L. Anthelmintic effects of condensed tannins on Trichostrongylus colubriformis in experimentally infected sheep. Semina: Ciencias Agrarias, Londrina, v. 31, n. 4, p. 1009-1016, 2010. 
MORTENSEN, L. L.; WILLIAMSON, L. H.; TERRILL, T. H.; KIRCHER, R.; LARSEN, R.; KAPLAN, R. M. Evaluation of prevalence and clinical implications of anthelmintic resistance in gastrointestinal nematodes of goats. Journal of the American Veterinary Medical Association, New York, v. 23, n. 4, p. 495-500, 2003.

MUTURI, K. N.; SCAIFE, J. R.; LOMAX, M. A.; JACKSON, F.; HUNTLEY, J.; COOP, R. L. The effect of dietary polyunsaturated fatty acids (PUFA) on infection with the nematodes Ostertagia ostertagi and Cooperia oncophora in calves. Veterinary Parasitology, Amsterdam, v. 129, n. 3-4, p. 273-283, 2005.

PUGH, D. G. Clínica de ovinos e caprinos. São Paulo: Roca, 2004.

ROBERTS, F. H. S.; O'SULLIVAN, S. P. Methods for egg counts and larval cultures for strongyles ingesting the gastrointestinal tract of cattle. Australian Journal of Experimental Agriculture, Austrália, v. 1, n. 1, p. 99-102, 1950.

ROCHA, R. A.; AMARANTE, A. F. T.; BRICARELLO, P. A. Comparison of the susceptibility of Santa Ines and Ile de France ewes to nematode parasitism around parturition and during lactation. Small Ruminant Research, Amsterdan, v. 55, n. 1, p. 65-75, 2004.

ROCHA, R. A.; ARAÚJO, J. V.; AMARANTE, A. F. T. Efficacy of the nematode-trapping fungus Duddingtonia flagrans against infections by Haemonchus and Trichostrongylus species in lambs at pasture. Journal Helminthology, Cambridge, v. 81, n. 4, p. 387-392, 2007.
ROCHA, R. A.; PACHECO, R. D. L.; AMARANTE, A. F. T. Efficacy of homeopathic treatment against natural infection of sheep by gastrointestinal nematodes. Brazilian Journal Veterinary Parasitology, Jaboticabal, v. 15, n. 1, p. 23-27, 2006.

SAÑUDO, C.; SIERRA, I. Calidad de la carnal em la especie ovina. Ovino, Barcelona, v. 1, n. 1, p. 127-153, 1986.

SAS, Statistical Analysis Systems Institute, SAS OnlineDoc $^{\circledR}$, Version 8, Cary, SAS Institute Inc., NC, 1999.

SCHALM, O. W.; CARROL, E. J. Veterinary hematology. Philadelphia: Lea \& Febiger, 1986.

STEAR, M. J.; MURRAY, M. Genetic resistance to parasitic disease: particularly of resistance in ruminants to gastrointestinal nematodes. Veterinary Parasitology, Amsterdam, v. 54, n. 1, p. 161-176, 1994.

STEEL, J. W. Effects of protein supplementation of young sheep on resistance development and resilience to parasite nematode. Australian Journal of Experimental Agriculture, Australian, v. 43, n. 12, p. 1469-1476, 2003.

ZACHARIAS, F.; GUIMARÃES, J. E.; ARAUJO, R.; ALMEIDA, M. A. O.; DIAS, A. V. S.; AYRES, M. C. C.; BAVIA, M. E.; MENDONÇA-LIMA, F. W. Alternative approach to control of Haemonchus contortus in sheep: evaluation of homeopathic treatment. 2007. Disponível em: $\quad<$ http://www.cesaho.com.br/publicacoes/index. aspx>. Acesso em: 05 maio 2007. 
